Relations industrielles

Industrial Relations

\title{
Chaison, Gary N., Union Mergers in Hard Times : The View From Five Countries
}

\section{Norman A. Solomon}

Volume 52, numéro 2, 1997

URI : https://id.erudit.org/iderudit/051177ar

DOI : https://doi.org/10.7202/051177ar

Aller au sommaire du numéro

Éditeur(s)

Département des relations industrielles de l'Université Laval

ISSN

0034-379X (imprimé)

1703-8138 (numérique)

Découvrir la revue

Citer ce compte rendu

Solomon, N. A. (1997). Compte rendu de [Chaison, Gary N., Union Mergers in Hard Times : The View From Five Countries]. Relations industrielles / Industrial Relations, 52(2), 458-460. https://doi.org/10.7202/051177ar

Tous droits réservés @ Département des relations industrielles de l'Université Laval, 1997
Ce document est protégé par la loi sur le droit d'auteur. L'utilisation des services d'Érudit (y compris la reproduction) est assujettie à sa politique d'utilisation que vous pouvez consulter en ligne.

https://apropos.erudit.org/fr/usagers/politique-dutilisation/ 
forcing path, the fostering path and combinations of forcing and fostering.

The authors' purpose in Pathways to Change is to provide the reader with the full text of the twelve case studies on which their theory of change is based. The cases are grouped under four strategy categories: forcing, fostering, sequence of forcing and fostering and interweaving forcing and fostering paths. Lessons are drawn from each case and general lessons are summarized in the last two chapters.

The authors' purpose has been successfully achieved. The book is extremely well organized, the case studies are well presented in full detail. The writing style creates interest in each of the case studies even though some of the cases are very long. The use of case studies is appropriate for the authors' purpose as it provides the reader with the complex elements present in each situation as they change through the time period covered.

While the authors have been successful in writing a companion book to their earlier text Strategic Negotiations, this book would be of interest to a limited audience. It would be chosen by readers of the earlier book who wanted the full detail of the case studies on which it is based.

The audience for the present book, Pathways to Change could be increased by providing a one chapter summary of the earlier book Strategic Negotiations in order to give the reader the essentials of the theory of change in labour-management relations. The case studies would then indicate how the theory was developed. In this way, the two books would be independent and complete in themselves commanding an enlarged readership. This excellent book deserves a wide readership as it addresses the most significant issue in labour-management relations today, in a most comprehensive way.

Quite apart from this alternative, Pathways to Change is highly recommended to all of those readers: students, faculty and practitioners who are interested in labour-management relations in general and negotiated change in particular.

TERRY HERCUS

University of Manitoba

\section{Union Mergers in Hard Times: The View From Five Countries}

by Gary N. CHAISON, Ithaca and London: ILR Press, 1996, 248 p., ISBN 0-80148380-8.

This book provides a useful comparative study of trade union mergers, a topic that has long interested industrial relations scholars and practitioners. The volume devotes a separate chapter to the union merger process in each of five nations: the United States; Canada; Great Britain; Australia; and New Zealand.

Chaison does a comprehensive job in each "country" chapter of discussing the role of mergers in the broader context of the significant recent changes to that country's industrial relations system. He shows how adverse economic conditions, increased nonunion competition, employer opposition to unionism and, on occasion openly hostile governments and active labour federations urged unions onto mergers or at least the active consideration of merger options. He also illustrates how, in some countries, labour laws also influenced mergers: either they encouraged mergers or served as weapons in the hands of those not in favour of mergers.

Following his discussion of the institutional context of mergers, Chaison reviews the country's merger record since 1980. In doing so he discusses landmark mergers, prominent merger forms, special conditions affecting mergers and actual or possible merger trends. This discussion leads to a country profile of union mergers. In his concluding chapter 
he reviews merger trends, compares the national profiles of union mergers and describes the common features of mergers in the five countries.

The author's main purpose in writing this book was to develop, in his words, "views of the broad sweep of union mergers in several countries - national profiles of merger activity during the hard times since 1980." He accomplishes this objective admirably and is able to distill from his analysis the distinct character of merger activity in each country that has evolved from the wider context of the country's industrial relations system. Thus in the United States the growing significance of the nonunion sector has impelled unions towards mergers in order to survive. Canadian unions, the author claims "are on the verge of a merger wave" because of three historic trends: the declining influence of international unions who can thus no longer block mergers of their Canadian sections; the consolidation of bargaining units (witness the CLRB's imposed consolidation of postal bargaining units and the subsequent "shotgun" marriage of the Canadian Union of Postal Workers [CUPW] and the Letter Carriers Union of Canada [LCUC]); and because of the trend towards superunions such as the Communications, Energy and Paperworkers Union of Canada (CEP) which have diverse memberships and see mergers as the path to expansion. In Britain the author discerns no "merger wave" but instead concludes that Britain has a tradition of union mergers facilitated by national legislation that provides a uniform merger approval process for all. Australia's merger movement has proceeded at a very rapid pace. This process was encouraged by both the federal government's and the Australian Council of Trade Unions desire to reduce union fragmentation, reform union structure and in general provide a spark that would enable the labour movement to operate in a more competitive economy. New Zealand witnessed a wave of mergers following 1987 legislation de- creeing a minimum size of 1000 members for all unions. However as a result the Employment Contracts Act of 1991 which severely undermined the status of unions as collective representatives of workers the merged unions are experiencing dramatic membership declines.

The author also, despite the complexity of the differences in the industrial relations systems of the five countries, identifies five common features of union mergers. Firstly, he examines the common impacts of union mergers on union members. Chaison carefully explains how mergers may or may not impact on individual members depending on the facts of a specific case. For example, in discussing what happens when a larger union absorbs a smaller union he states that it is common for the smaller union to continue its usual governing practices because the resources required to do so are not great. On the other hand there may be some mergers of large unions where the impact on members is readily felt because the new organization cannot maintain two separate and large infrastructures. Thus for example, when CUPW merged with LCUC there was a major change in the governance of the latter.

Secondly, Chaison finds that advocates of union mergers in each nation are "almost universally" biased against small unions. The greatest resistance was found in Australia and New Zealand which actually have had legally mandated minimum size requirements for unions. The author, while refusing to enter the "union size/effectiveness" debate does point out that small size can work for unions that negotiate only a limited number of collective agreements or that represent specialized groups of workers in specific geographic areas.

Thirdly, Chaison found that tension between the desire of central labour federations to rationalize jurisdictions and the desires of federation members to expand their membership base underlies 
many of the recent mergers in the countries studied. Thus Chaison notes that some labour federations, such as the AFLCIO support mergers of unions with "communities of interests" while federation members may merge based on other grounds. For example, the Communication Workers of America accepted the 12,000 member Combined Law Enforcement Association of Texas as an affiliate because the CWA already had a strong presence in that state.

Fourthly, the author finds that union mergers are essentially voluntary. He indicates that while governments may enact legislation to encourage mergers and central labour federations may favour mergers, "the ultimate decision of when, how and with whom to merge remains within the union". Thus even in the merger of CUPW and the LCUC the unions were first invited to negotiate merger terms and when that failed the members were free to choose a single union to represent them.

Finally, Chaison concludes that in all the countries studied mergers represent adaptations to difficult times. They do not solve the fundamental problems - such as increased nonunion competition - that help spawn mergers. Mergers are merely a way to deal with "slow decline, eventual disbandment and the loss of em- ployment for union officers and representation for members."

Chaison has proven his central theme well, "that merging has become synonymous with the evolution of unions; that at the start of the next century, the largest, most powerful and fastest growing unions will have been created and fortified by union mergers." The author's work represents an intense effort at institutional scholarship on trade unions. The comparative focus of this effort is unique and Chaison deserves much credit for forging new ground in the area of comparative industrial relations. My only concern about the volume is that not enough attention is paid to developing a conceptual framework within which to analyse the very rich data collected. However this is a pioneering effort and I hope that as additional "country" studies of union mergers become available Chaison and other comparative industrial relations scholars will be able to develop a more rigorous conceptual framework that will further explain the similarities and differences of various labour movements. This being said Chaison's volume belongs on the bookshelf of every serious scholar of trade unionism and of comparative industrial relations.

NORMAN A. SOLOMON University of Windsor

\section{Local and Regional Response to Global Pressure: The Case of Italy and its Industrial Districts}

publié sous la direction de Francesco COSSENTINO, Frank PIKE et Werner SENGENBERGER, Genève : International Institute of Labour Studies, research series 103, 1996, 206 p., ISBN 92-9014-568-4.

La mondialisation est le sujet de l'heure. Comme par le passé avec la révolution industrielle et la prolifération des marchés, la croissance de l'économie internationale s'accompagne d'une littérature sur l'habileté de différentes entités à y prendre part. L'ouvrage publiée sous la direction de Cossentino, Pike et Sengenberger s'inscrit dans cette littérature. Il fait suite à un séminaire visant à identifier les meilleurs choix politiques en matière d'adaptation des districts industriels italiens à une compétition internationale accrue.

L'intérêt renouvelé pour les districts industriels italiens tient à leur bonne performance des dernières décennies au plan de l'emploi et des conditions de travail et à une structure industrielle caractérisée 